\title{
ECOLOGICAL STUDY IN TWO QUARRIED LIMESTONE KARST HILLS IN BOGOR WEST JAVA: VEGETATION STRUCTURE AND FLORISTIC COMPOSITION
}

\author{
ANNISA SATYANTI and YAYAN WAHYU CANDRA KUSUMA \\ Centre for Plant Conservation Bogor Botanic Gardens Indonesia \\ Indonesian Institute of Science
}

Received 04 May 2010 / Accepted 23 October 2010

\begin{abstract}
Many species extinctions have probably gone unnoticed on limestone that was destroyed before they could be sampled. Unless biodiversity surveys are intensified, the true magnitude of extinctions will never be ascertained. The objectives of this study were to determine tree species composition of limestone hills in Nyungcung and Ciampea; to determine quantitatively the dominant and less dominant species and to quantify floristic structure of the two limestone hills. Value of richness (Menhinick) and evenness in Nyungcung were 3.28 and 0.826 while in Ciampea were 3.29 and 0.823 , respectively. In term of diversity (Shannon Wiener), Nyungcung seems to be more diverse than Ciampea as indicated by the higher value of diversity index. Nyungcung has 3.225 of diversity (Shannon Wiener) index while Ciampea has 2.859. The floristic composition of two sites was significantly different and mostly comprised Moraceae, Rubiaceae, and Euphorbiaceae. However, the highest presence of species were Antidesma montanum (Euphorbiaceae) and Chrysophyllum lanceolatum (Sapotaceae), and Pandanus sp. (Pandanaceae) in Nyungcung, whereas in Ciampea, Harpullia arborea (Sapindaceae), Ophiorbhiza canescens (Rubiaceae), and Allophyllus cobbe (Sapindaceae). Macaranga rbizinoides, O. canescens, $A$. montanum, and Turpinia montana, respectively, gained the highest importance values.
\end{abstract}

Keywords: limestone, flora, composition, quarries

\section{INTRODUCTION}

On the highly fragmented Sunda shelf, limestone karsts, hereafter simply referred as karsts, "islands within islands" have been formed, and these are known to contain reservoirs of biodiversity with high level of endemism. Limestone karsts are

\footnotetext{
*Corresponding author : a.satyanti@gmail.com
} 
sedimentary rock outcrops that consist primarily of calcium carbonate. Most karsts were formed millions of years ago by calcium-secreting marine organisms (e.g., corals and brachiopods) before tectonic movements lifted them above sea level. Over the years, the softer sediments covering these karsts were removed by mechanical and chemical weathering (Clements et al. 2006). The many karst hills in Bogor have been saved from agricultural threats for their rugged terrain, but they are now prone to mining. The mining of limestone and basement minerals are a primary threat to karst biotas because they cause extirpations of site endemic taxa (Clements et al.2006).

The existence of vegetation was very important for karsts ecosystem for its role in absorbing and supplying water in the area. The absence of vegetation would cause insufficient water supply during the dry season. Karsts vegetation also had an important role for the livelihood of other ecosystem components. For instance, in Southern Sulawesi limestone karst ecosystem is important for the survival of rangkong (Nicticeros cassidix) as well as monyet Sulawesi (Macaca maura) that depends on vegetation as their habitat and food source (Himakova IPB et al. 2007). In Ciampea limestone hill, long-tailed monkeys (Macaca fascicularis) depend on fruit and foliage. Limestone is also a strategic natural resource; the United Nations estimate that approximately $25 \%$ of the world population water demand is supplied by karst water (Ko 1997).

In addition, site-endemic species face the greatest extinction risk when a karst is completely quarried, e.g. Zeuxine tjiampeana J.J. Sm. that is confirmed to be endemic by Comber (1990) to a limestone mountain in Ciampea, Bogor. Many species extinctions have probably gone unnoticed on karsts that were destroyed before they could be sampled. Unless biodiversity surveys of karsts are intensified, the true magnitude of extinctions will never be ascertained. A limestone species might not be listed as endangered species and protected without assessment study.

Until now very scant attention has been given to the impact of quarries on limestone flora diversity including limestone flora in Java. A study on limestone karst system of plant diversity would help increase biodiversity protection and maintain natural landscape. It is important to identify flora losses due to presence of quarries as it will encompass species that are able to adapt to such system and further indicate specific plant species that can be employed for restoration. The objectives of this study were to determine tree species composition of the study area; to determine quantitatively the dominant and less dominant species and to quantify floristic structure of the two limestone hills.

\section{MATERIALS AND METHODS}

\section{Sites}

Sampling for vegetation survey took place on two limestone hills situated in west of Bogor West Java (Fig. 1), i.e. Gunung Kapur Ciampea $\left(106^{\circ} 41^{\prime} 00.0^{\prime \prime} \mathrm{E}\right.$ and $06^{\circ} 33^{\prime}$ $\left.00.0^{\prime \prime} \mathrm{S}\right)$ and Gunung Nyungcung (106 38' 00.0" E and $\left.06^{\circ} 27^{\prime} 00.0^{\prime \prime} \mathrm{S}\right)$. 


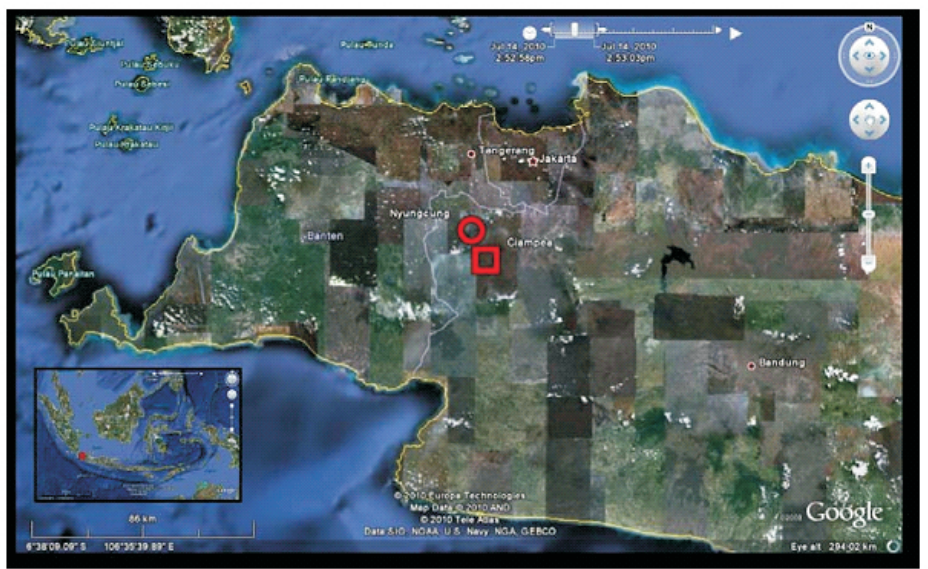

Figure 1. Sites, Ciampea (lower right box) and Nyungcung limestone hill (upper left circle).

The limestone site in Ciampea is a long coral reef raised to above $350 \mathrm{~m}$ above sea level. The formation of limestone is of the Bojongmanik formation. Limestone contains molluscs; the unit is as lenses within the Bojongmanik formation which is equal to a middle Mioscene age (Effendi et al. 1998). The forest used to have numerous Dipterocarpus hasseltii (Dipterocarpaceae), Stelechocarpus burahol (Annonaceae), and a number of Diospyros (Ebenaceae) but no single species was dominant (van Steenis 1931 in Whitten \& Soeriaatmadja 1997). There is no information of previous studies available for limestone karst in Nyungcung.

The two sites were already quarried. A quarry here refers to a surface mining operated place, which produces enormous quantities of gravel, limestone, and other materials for industrial and construction application. The quarry in Ciampea apparently employed traditional and modern modes; locals also used explosive substance for mining, whereas in Nyungcung, excavators and other modern equipments were used. The exact period of quarries in both sites is unknown. Local people mentioned that it most probably started in the nineteen eighties.

The panorama of the site can be described as newly operated quarries, abandoned or old quarries, and covered area. Old quarries impose a significant negative visual impact, while on the other hand pose serious soil erosion and degradation (Fig. 2 and 3). 


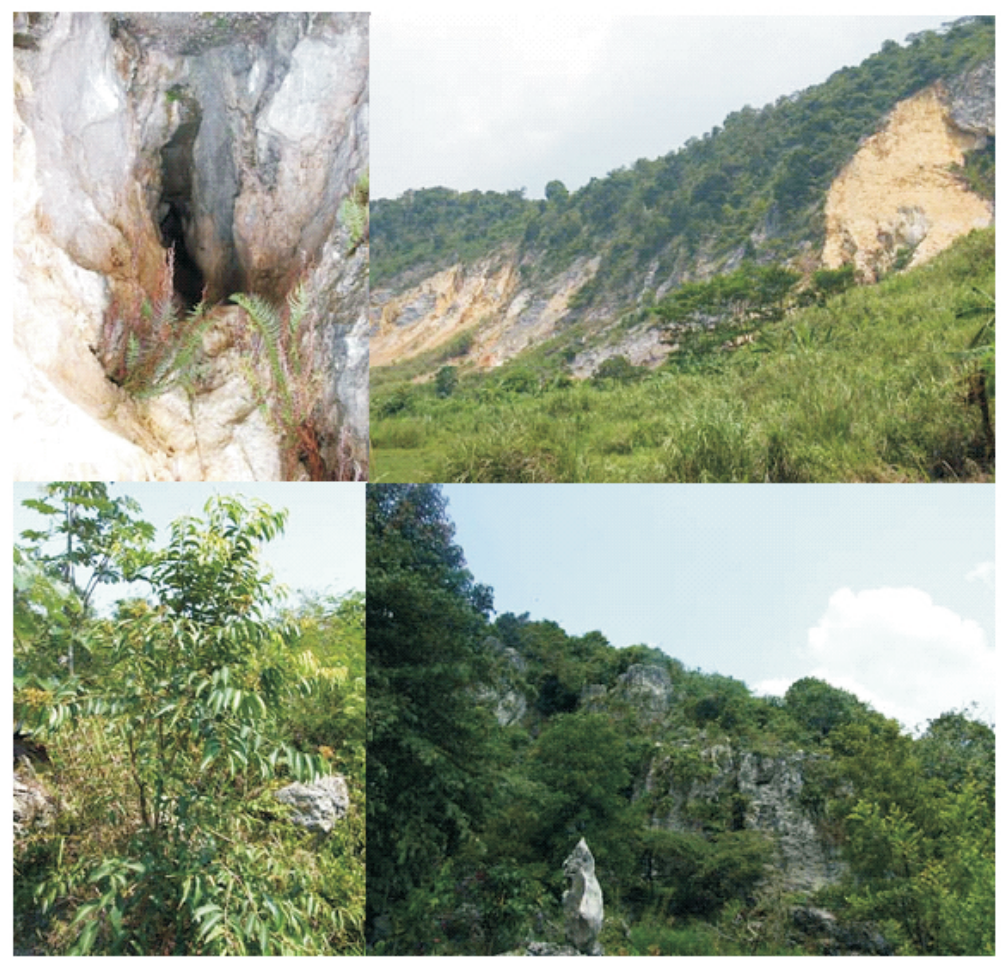

Figure 2. Ciampea limestone panorama and vegetation cover.

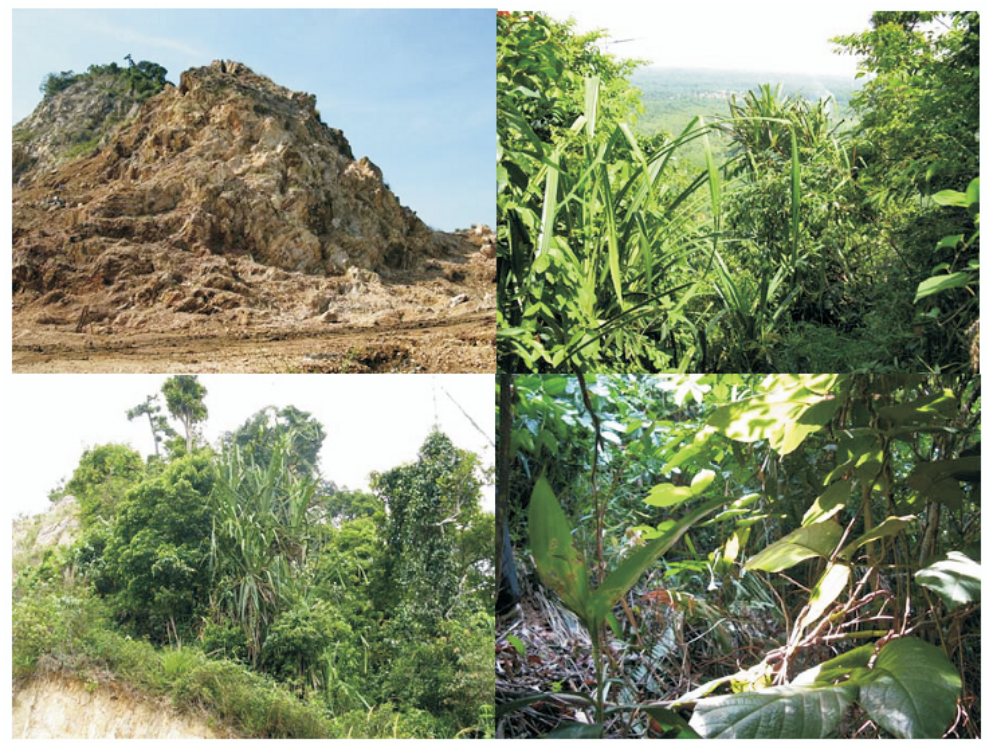

Figure 3. Nyungcung limestone panorama and vegetation cover. 


\section{Plot set up}

Six plots in each limestone hill were established, leading to a total of 12 plots. The size of each plot was $6 \mathrm{~m} \times 6 \mathrm{~m}$, which was determined by preliminary investigation on the species number plotted in a graph. When the number is levelling or reaching the plateau, the size of plot is then determined as a plot measure. The distribution of sampling plots was through purposive random selection.

\section{Vegetation analysis}

Quarry intensity in Nyungcung can be defined as very intensive, resulting in flat quarries over area with barely any vegetation. In addition, in Ciampea, the limestone karst was extensively quarried in a moderate intensity, giving the opportunity for pioneer species to form succession on left over hill (Fig. 2).

The vegetated areas in both sites were confined and mostly difficult to access, especially in Nyungcung. The remaining forest in Nyungcung limestone hill is very confined and is situated on the peak. The hill itself was almost $70 \%$ quarried, and the activity started in 1980s (Fig. 3).

The measurement was conducted on those with remaining vegetation. A total of 12 plots were established. Plant parts were gathered and further pressed to become herbarium for species determination. Measurement was done for woody species, diameter at breast height and height. Basal area and height for woody species were also calculated to provide overview for stocking and phytomass.

Diameter of seedling and shrubs were measured at about one inch above ground. For climber, height was irrelevant and thus data for height was absent. For prominent herbaceous plant and fern, only species identity was recorded. Aside from vegetation analysis, environmental data were collected viz.: soil $\mathrm{pH}$, soil relative humidity, air temperature, air humidity, and solar radiation.

\section{Data analysis}

All voucher specimens collected were identified in Bogor Botanic Garden and Herbarium Bogoriense. The overall floristic richness, diversity, and evenness of species between plots were quantified using The Menhinick Richness index $(\mathrm{R} 2)=\frac{\mathrm{S}}{\sqrt{n}}$; where $S$ is the number of species, and $n$ is the number of individuals. Shannon-Wiener Diversity Index $\left(H^{\prime}\right)=-\sum_{i=1}^{\mathrm{s}}(\rho i 1 \mathrm{n} \rho \imath)$, where $\rho i$ is relative abundance of each species, calculated as the proportion of individuals of a given species to the total number of individuals in the community and Evenness Index $(E)=\frac{H^{\prime}}{\ln (S)}($ Ludwig $\&$ Reynolds 1988). Significant difference was tested using unpaired t-tests for Menhinick richness index and ShannonWiener diversity. ANOSIM was also employed to calculate dissimilarity for comparing diversity of the groups. ShannonWiener diversity and ANOSIM was performed using Vegan packages and Biodiversity $\mathrm{R}$ in R software (R Development Core Team 2010; Kindt \& Coe 2005; Fox et al. 2010; Oksanen et al. 2010) whilst Menhinick richness and unpaired t-test was performed using excel add ins. 
Importance values referring to the measure of the relative dominance of species in a forest community was counted. Importance values rank species within a site based upon three criteria viz. how common a species occurs across the site (relative frequency; species $/ \mathrm{m}^{2}$ ); the total number of individuals of the species (relative density; individual/species); and the basal area of the species (relative dominance; $\mathrm{m}^{2} /$ species).

\section{RESULTS AND DISCUSSION}

\section{Species dominance and floristic structure}

Floristic richness in Nyungcung and Ciampea were significantly different $(\mathrm{t}=$ 2.228, $\mathrm{df}=10, \rho=0.02)$, as well as its evenness index $(\mathrm{t}=2.306$, $\mathrm{df}=10, \rho=0.03)$. Value of richness and evenness in Nyungcung were 2.99 \pm 0.84 and $0.865 \pm 0.03$, respectively, while in Ciampea $2.4 \pm 0.33$ and $0.828 \pm 0.04$. In term of diversity, Nyungcung was more diverse than Ciampea as indicated by the higher value of diversity index. Nyungcung had $2.65 \pm 0.24$ of diversity index, while Ciampea has $2.28 \pm 0.23(\mathrm{t}=2.228$, $\mathrm{df}=10, \rho=0.02)$. As comparison, the diversity indices of limestone forest in Bau Hill (Adam \& Mamat 2005) were 3.72, 3.28, and 2.79 at three different altitude levels of 15,30 , and $50 \mathrm{~m}$, respectively.

Moreover, ANOSIM analysis also showed that Nyungcung and Ciampea were also significantly different based on its ecological distance $(R=0.928, \rho=0.002)$, where 0

Table 1 . Presence of flora identified within Ciampea and Nyungcung vegetation analysis plot

\begin{tabular}{|c|c|c|c|c|c|}
\hline Species & Nyungcung & Ciampea & Species & Nyungcung & Ciampea \\
\hline Acronycbia pedunculata & 3 & 0 & Glocbidion rubrum & 1 & 0 \\
\hline Allopbyllus cobbe & 2 & 30 & Gluta renghas & 7 & 0 \\
\hline Alstonia scholaris & 6 & 0 & Glycosmis pentaphylla & 0 & 1 \\
\hline Antidesma montanum & 46 & 13 & Guioa diplopetala & 0 & 2 \\
\hline Aporosia octandra & 3 & 0 & Harpullia arborea & 0 & 34 \\
\hline Arcbidendron fagifolium & 1 & 0 & Homalanthus populneus & 0 & 7 \\
\hline Arenga pinnata & 2 & 0 & Ixora javanica & 0 & 3 \\
\hline Artbropbyllum diversifolium & 11 & 0 & Ixora sp. & 1 & 0 \\
\hline Artocarpus beteropbyllus & 1 & 0 & Jasminum sp. & 1 & 0 \\
\hline Breynia racemosa & 0 & 1 & Kibara coriacea & 2 & 0 \\
\hline Bridelia tomentosa & 0 & 3 & Kleinhovia bospita & 2 & 0 \\
\hline Buchanania arborescens & 0 & 1 & Lasianthus inodorus & 4 & 0 \\
\hline Calliandra callotbyrsus & 0 & 14 & Lasianthus lucidus & 1 & 0 \\
\hline Cassearia coriaceae & 0 & 1 & Leea rubra & 0 & 6 \\
\hline Cecropia palmata & 0 & 4 & Litsea glutinosa & 0 & 24 \\
\hline Cecropia sundaica & 0 & 2 & Litsea umbellata & 0 & 1 \\
\hline Chrysopbyllum lanceolatum & 29 & 0 & Lucuma petaloides & 0 & 18 \\
\hline Cinnamomum iners & 0 & 1 & Macaranga rbizinoides & 2 & 23 \\
\hline Clerodendrum serratum & 0 & 4 & Melastoma malabathricum & 0 & 2 \\
\hline Cratoxylum formosum & 1 & 0 & Microcos birsuta & 6 & 1 \\
\hline Croton tiglium & 0 & 2 & Mischocarpus fuscescens & 10 & 0 \\
\hline Daemonorops sp. & 1 & 0 & Mischocarpus sundaicus & 8 & 0 \\
\hline Dalbergia rostrata & 1 & 0 & Moraceae sp. & 1 & 0 \\
\hline Dendrocnide sinuata & 0 & 3 & Morinda citrifolia & 0 & 2 \\
\hline Dillenia obovata & 1 & 0 & Ophiorrbiza canescens & 6 & 30 \\
\hline Dioscorrea bispida & 3 & 0 & Orophea bexandra & 2 & 1 \\
\hline Diospyros maritima & 0 & 1 & Pandanus sp. & 28 & 0 \\
\hline Diplospora singularis & 0 & 1 & Peltophorum pterocarpum & 3 & 0 \\
\hline Elaeocarpus floribundus & 2 & 0 & Phyllanthus reticulatus & 0 & 2 \\
\hline Endiandra rubescens & 6 & 0 & Pleomele elliptica & 10 & 0 \\
\hline Erythroxylum cuneatum & 2 & 0 & Poikilospermum sp. & 0 & 3 \\
\hline Fagraea racemosa & 0 & 1 & Premna pubescens $\mathrm{B} 1$. & 0 & 1 \\
\hline Ficus annulata & 1 & 0 & Psychotria angulata & 0 & 1 \\
\hline Ficus fistulosa & 0 & 2 & Pterospermum javanicum & 0 & 1 \\
\hline Ficus grossularoides & 3 & 0 & Pycnarrhena cauliflora & 1 & 0 \\
\hline
\end{tabular}


Table 1 . Continued

\begin{tabular}{|c|c|c|c|c|c|}
\hline Species & Nyungcung & Ciampea & Species & Nyungcung & Ciampea \\
\hline Ficus birta & 18 & 0 & Randia maculata & 0 & 6 \\
\hline Ficus montana & 1 & 1 & Stephania japonica & 0 & 1 \\
\hline Ficus pinnata & 0 & 1 & Sterculia coccinea & 1 & 0 \\
\hline Ficus sagittata & 3 & 0 & Streblus asper var asper & 0 & 1 \\
\hline Ficus septica & 0 & 5 & Syzygium lineatum & 9 & 14 \\
\hline Ficus sp 1 & 0 & 1 & Syzygium pycnathum & 2 & 0 \\
\hline Ficus sp 2 & 0 & 7 & Syzygium racemosum & 22 & 7 \\
\hline Ficus sp 3 & 0 & 8 & Tetracera akara & 1 & 0 \\
\hline Ficus sp 4 & 0 & 27 & Tetracera scandens & 1 & 4 \\
\hline Ficus sp 5 & 0 & 1 & Tristellatcia australaciae & 5 & 0 \\
\hline Ficus sp 6 & 1 & 0 & Turpinia montana & 15 & 0 \\
\hline Flacourtia rukam & 2 & 0 & Urena lobata & 0 & 2 \\
\hline Flagellaria indica & 1 & 0 & Vitex pinnata & 4 & 1 \\
\hline Garcinia dulcis & 2 & 0 & Vitex quinnata & 0 & 1 \\
\hline Garcinia lateriflora & 2 & 0 & & & \\
\hline Garcinia parvifolia & 5 & 0 & & & \\
\hline Glochidion philippicum & 1 & 3 & & & \\
\hline
\end{tabular}

$=$ highly similar and $1=$ highly dissimilar. This indicated that both sites have different species composition. As shown in the Table 1, many species which composed Nyungcung limestone forest were absent in Ciampea and conversely. The largest family composing the limestone quarried areas was Moraceae, subsequently followed by Rubiaceae and Euphorbiaceae. The identified perennial species within vegetation analysis plot belong to 38 families (Fig. 5 and Table 2). This was probably as a result of differences in disturbance level.

Figure 4 shows the accumulation of species in each plot, depicting accrued number of species as the number of plot increased, and higher number of species found in Nyungcung compared to Ciampea. Forests on limestone have few tree species in general compared to forests on deeper soils (Crowther 1982; Proctor et al. $1983 \mathrm{a}, \mathrm{b}$ ), although the total number of plant species is probably not dissimilar to other forest types (Whitten \& Soeriaatmadja 1997). Some trees of lowland forest

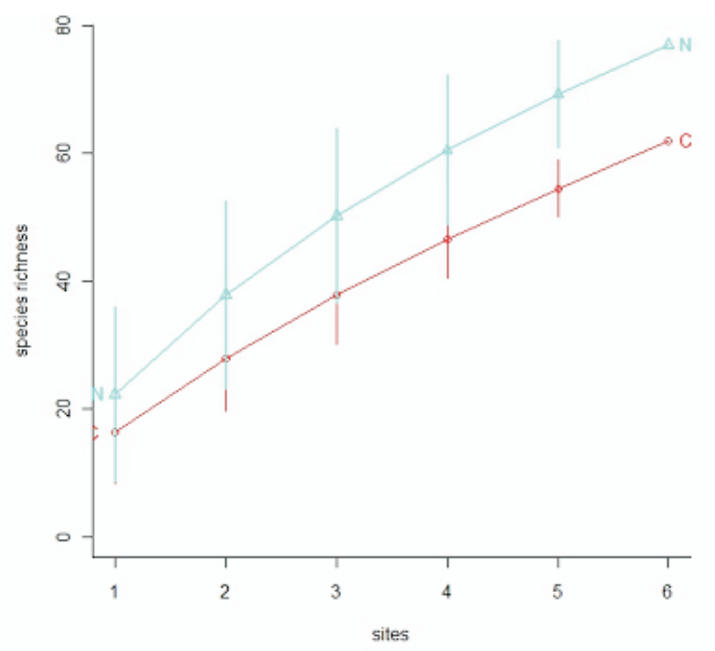

Figure 4. Species accumulation curve $(\mathrm{N}=$ Nyungcung, $\mathrm{C}=$ Ciampea), referring to total number species as the plotincreased. 
cannot tolerate the high soil calcium levels which may lead to the relative paucity of tree species. The different tolerance of trees to calcium and the unique physical habitat of limestone make the composition of these forests rather different from other lowland forest, giving rise to a specific community of trees.

Nevertheless, we could not find a very specific species that encompass its capability to cope with these abiotic circumstances. This confirms the fact that despite being fairly well studied, there are apparently no plants on Java that are specific to limestone (van Steenis 1931, van der Pijl 1933 in Whitten \& Soeriaatmadja 1997), a striking contrast to the situation in Peninsular Malaysia where $21 \%$ of limestone flora is restricted to the limestone habitat, generally isolated to tower karst hills, and half of those are endemic to the peninsula (Chin 1977, 1983). Our finding also showed that the diversity of limestone in Ciampea and Nyungcung were lower compared to those of Sarawak.

Table 2. Families, Density, and the Basal Area of Flora Composing Limestone Hills in Nyungcung and Ciampea

\begin{tabular}{|c|c|c|c|c|c|c|c|c|c|}
\hline \multirow[b]{2}{*}{ Family } & \multicolumn{4}{|c|}{ Nyungcung } & \multicolumn{5}{|c|}{ Ciampea } \\
\hline & $\begin{array}{c}\text { Nr of } \\
\text { species }\end{array}$ & Density & $\%$ density & BA & $\begin{array}{c}\text { Nr of } \\
\text { species }\end{array}$ & Density & $\begin{array}{c}\% \\
\text { density }\end{array}$ & & BA \\
\hline Anacardiaceae & 1 & 8 & 2.90 & 33.70 & 1 & 1 & 0.27 & & 0.52 \\
\hline Annonaceae & 1 & 1 & 0.36 & 0.66 & 1 & 1 & 0.27 & & 0.06 \\
\hline Apocynaceae & 1 & 6 & 2.17 & 23.55 & - & - & - & - & \\
\hline Araliaceae & 1 & 11 & 3.99 & 148.15 & - & - & - & - & \\
\hline Clusiaceae & 3 & 9 & 3.26 & 27.28 & - & - & - & - & \\
\hline Dilleniaceae & 2 & 2 & 0.72 & 39.29 & 1 & 4 & 1.08 & & 5.51 \\
\hline Dioscoreaceae & 1 & 1 & 0.36 & 0.10 & & & & & \\
\hline Ebenaceae & - & - & - & - & 1 & 1 & 0.27 & & 3.36 \\
\hline Elaeocarpaceae & 1 & 2 & 0.72 & 1.45 & - & - & - & - & \\
\hline Hypericaceae & 1 & 1 & 0.36 & 1.29 & - & - & - & - & \\
\hline Lauraceae & 1 & 6 & 2.14 & 8.36 & 3 & 26 & 6.99 & & 31.60 \\
\hline Leeaceae & - & - & - & - & 1 & 6 & 1.61 & & 5.91 \\
\hline Liliaceae & 1 & 6 & 2.14 & 3.63 & - & - & - & - & \\
\hline Loganiaceae & & & & & 1 & 1 & 0.27 & & 6.37 \\
\hline Malvaceae & & & & & 1 & 2 & 0.54 & & 0.21 \\
\hline Malpighiaceae & 1 & 4 & 1.43 & 20.77 & & & & & \\
\hline Melastomataceae & & & & & 1 & 2 & 0.54 & & 0.81 \\
\hline Menispermaceae & 1 & 1 & 0.36 & 0.53 & 1 & 1 & 0.27 & & 0.01 \\
\hline Rutaceae & 1 & 3 & 1.07 & 5.21 & 1 & 1 & 0.27 & & 0.05 \\
\hline Sapindaceae & 3 & 20 & 7.14 & 25.64 & 3 & 66 & 17.74 & & 23.12 \\
\hline Sapotaceae & 1 & 29 & 10.36 & 72.58 & 1 & 18 & 4.84 & & 19.15 \\
\hline Staphyllaceae & 1 & 15 & 5.36 & 143.33 & - & - & - & - & \\
\hline Sterculiaceae & 2 & 3 & 1.07 & 7.27 & 1 & 1 & 0.27 & & 5.38 \\
\hline Tilliaceae & 2 & 6 & 2.14 & 26.44 & 1 & 1 & 0.27 & & 0.11 \\
\hline Urticaceae & - & - & - & - & 3 & 12 & 3.23 & & 35.88 \\
\hline Verbenaceae & 1 & 4 & 1.43 & 7.60 & 3 & 7 & 1.88 & & 17.84 \\
\hline
\end{tabular}


In both sites it can be inferred that Euphorbiaceae, and Moraceae were dominant. In addition to the two families, Myrtaceae and Sapotaceae were abundant in Nyungcung, whereas in Ciampea, they were Sapindaceae and Rubiaceae (Table 1 and Fig. 5). Antidesma montanum (Euphorbiaceae), Chrysophyllum lanceolatum (Sapotaceae), and Pandanus sp. (Pandanaceae) were found to be very abundant in Nyungcung but less in Ciampea, whereas, Macaranga rbizinoides, Harpullia arborea, Allophyllus cobbe, and Ophiorrbiza canescens were abundant in Ciampea (Table 1; Table 3). Urticaceae, Melastomataceae, and Malvaceae that commonly structure open vegetation were not found in Nyungcung, where the light intensity under the stand was relatively lower compared to Ciampea (Table 1 and Fig. 5).

Table 3. Summary of Species found in Nyungcung and Ciampea Hills with its respective Relative Density (RD), Relative Frequency (RF), and Relative Dominance (RDm). Species shown were confined to those with Importance Values $(\mathrm{Iv}) \geq 3.69$

\begin{tabular}{|c|c|c|c|c|c|}
\hline \multirow{2}{*}{ Species } & \multirow{2}{*}{ Family } & \multicolumn{4}{|c|}{ Nyungcung } \\
\hline & & RD & RF & RDm & Iv \\
\hline Antidesma montanum & Euphorbiaceae & 16.91 & 5.50 & 1.24 & 23.65 \\
\hline Turpinia montana & Staphyleaceae & 2.21 & 3.67 & 15.68 & 21.55 \\
\hline Arthrophyllum diversifolium & Araliaceae & 0.74 & 0.92 & 18.00 & 19.65 \\
\hline Chrysophyllum lanceolatum & Sapotaceae & 10.66 & 2.75 & 0.00 & 13.41 \\
\hline Syzygium racemosum & Myrtaceae & 6.62 & 5.50 & 0.00 & 12.12 \\
\hline Syzygium sp. & Myrtaceae & 6.62 & 4.59 & 0.13 & 11.34 \\
\hline Ficus birta & Moraceae & 5.51 & 4.59 & 0.00 & 10.10 \\
\hline Gluta renghas & Anacardiaceae & 0.00 & 0.00 & 9.91 & 9.91 \\
\hline Microcos birsuta & Tiliaceae & 4.04 & 3.67 & 0.00 & 7.71 \\
\hline Ophiorrbiza canescens & Rubiaceae & 4.41 & 2.75 & 0.01 & 7.17 \\
\hline Mischocarpus fuscescens & Sapindaceae & 0.00 & 0.00 & 7.05 & 7.05 \\
\hline Vitex pinnata & Verbenaceae & 1.47 & 3.67 & 1.46 & 6.60 \\
\hline Mischocarpus sundaicus & Sapindaceae & 2.57 & 3.67 & 0.00 & 6.24 \\
\hline Alstonia scholaris & Apocynaceae & 2.21 & 3.67 & 0.01 & 5.89 \\
\hline Kibara coriacea & Monimiaceae & 2.94 & 2.75 & 0.00 & 5.69 \\
\hline Endiandra rubescens & Lauraceae & 0.00 & 0.00 & 5.61 & 5.61 \\
\hline Dillenia obovata & Dilleniaceae & 3.68 & 1.83 & 0.00 & 5.51 \\
\hline Garcinia parvifolia & Clusiaceae & 0.00 & 0.00 & 5.16 & 5.16 \\
\hline Peltophorum pterocarpum & Fabaceae & 0.00 & 0.00 & 4.66 & 4.66 \\
\hline Ficus grossularoides & Moraceae & 2.21 & 1.83 & 0.00 & 4.04 \\
\hline Macaranga rbizinoides & Euphorbiaceae & 7.84 & 5.32 & 18.00 & 31.15 \\
\hline Ophiorrbiza canescens & Rubiaceae & 8.11 & 3.19 & 15.68 & 26.98 \\
\hline Allophyllus cobbe & Sapindaceae & 8.11 & 5.32 & 1.38 & 14.81 \\
\hline Alchornea rugosa & Euphorbiaceae & 5.95 & 3.19 & 5.61 & 14.75 \\
\hline Harpullia arborea & Sapindaceae & 9.19 & 3.19 & 1.63 & 14.02 \\
\hline Lucuma petaloides & Sapotaceae & 4.86 & 6.38 & 2.50 & 13.75 \\
\hline Ficus sp.4 & Moraceae & 7.30 & 1.06 & 5.16 & 13.52 \\
\hline Ficus fistulosa & Moraceae & 0.54 & 2.13 & 9.91 & 12.58 \\
\hline Litsea glutinosa & Lauraceae & 6.49 & 2.13 & 3.55 & 12.17 \\
\hline Sysygium picnanthum & Myrtaceae & 5.14 & 4.26 & 1.98 & 11.37 \\
\hline Ficus sp. 2 & Moraceae & 1.89 & 2.13 & 7.05 & 11.07 \\
\hline Calliandra callothyrsus & Fabaceae & 3.78 & 2.13 & 4.66 & 10.57 \\
\hline Piper aduncum & Piperaceae & 3.24 & 4.26 & 1.05 & 8.55 \\
\hline Antidesma montanum & Euphorbiaceae & 3.51 & 3.19 & 1.24 & 7.94 \\
\hline Ficus sp.3 & Moraceae & 2.16 & 1.06 & 2.29 & 5.51 \\
\hline Ficus septica & Moraceae & 1.35 & 3.19 & 0.80 & 5.34 \\
\hline Randia patula & Rubiaceae & 1.62 & 2.13 & 0.85 & 4.60 \\
\hline Ixora javanica & Rubiaceae & 0.81 & 2.13 & 1.07 & 4.01 \\
\hline Tetracera scandens & Dilleniceae & 1.08 & 2.13 & 0.72 & 3.93 \\
\hline Bridelia tomentosa & Euphorbiaceae & 0.81 & 2.13 & 0.75 & 3.69 \\
\hline
\end{tabular}




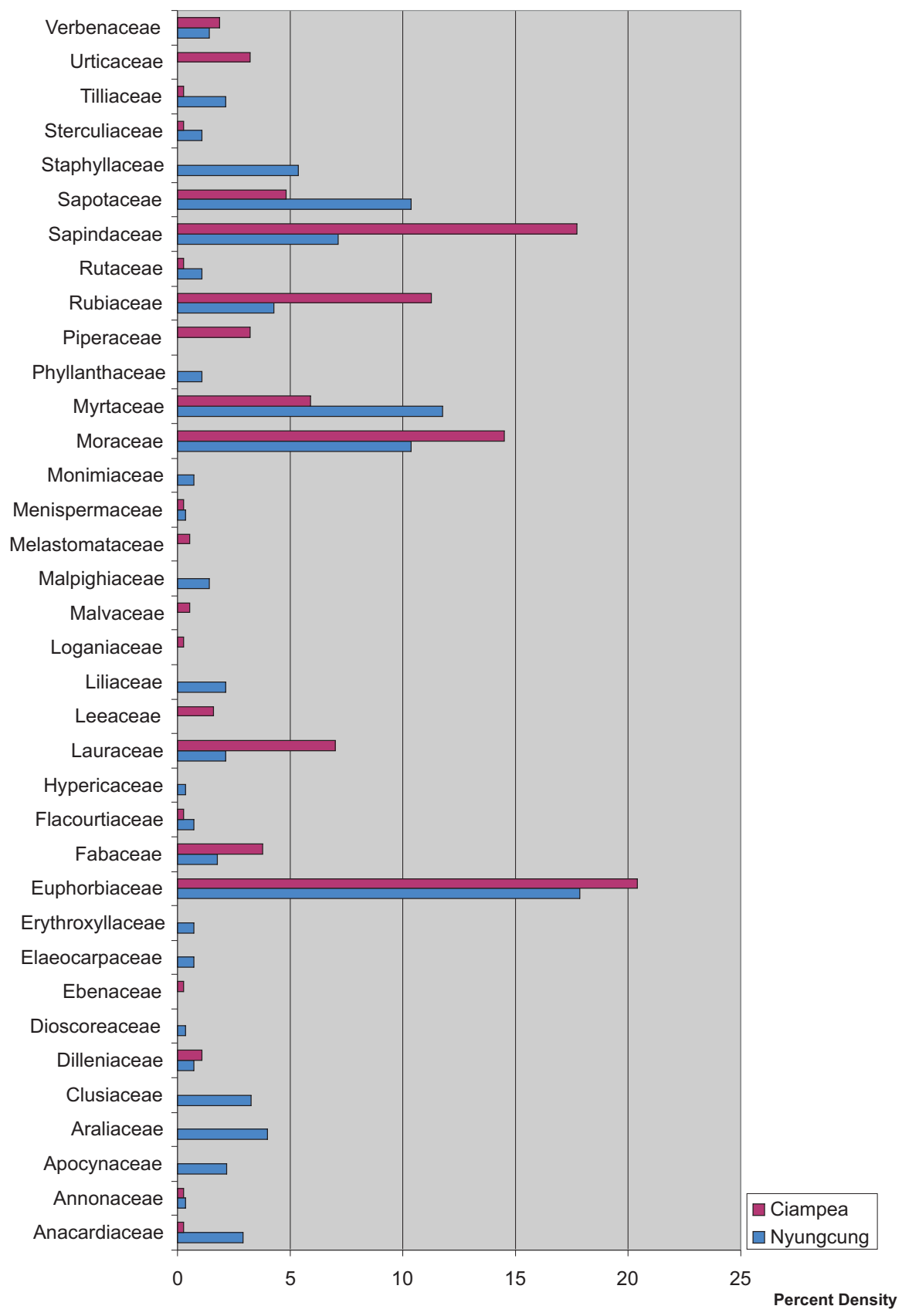

Figure 5. Family Composition on Quarried Limestone Hills in Ciampea and Nyungcung 
Macaranga rbizinoides, Ophiorrbiza canescens, Antidesma montanum, and Turpinia montana, respectively, gained the highest importance values (Iv) as shown in Table 3. However, this was not consistent for the composing relative density, relative frequency, and its relative dominance. Species with the highest relative density were Antidesma montanum, Chrysophyllum lanceolatum, and Harpullia arborea. Species with the highest relative frequency were Lucuma petaloides, Antidesma montanum, and Syzygium racemosum; whereas the highest relative dominance was for Macaranga rhizinoides, Arthrophyllum diversifolium, Ophiorrbiza canescens, and Turpinia montana. Buchanania arborescens as well as Gluta renghas (Anacardiaceae) were frequently found on the two limestone hills.

Aside from species occurrence that was depicted in the plot, some species were also found in Nyungcung during the preliminary survey including: Cratoxylum formosum (Hypericaceae), Dillenia ovata (Dilleniaceae), Spatholobus ferrugineus (Fabaceae), Uncaria cordata (Rubiaceae), Decaspermum parviflorum (Myrtaceae), Artocarpus glaucus (Moraceae), Ficus retusa (Moraceae), Alseodaphne umbelliflora (Lauraceae), Derris multiflora (Fabaceae), Dioscorea hispida (Dioscoreaceae), Sysygium cuminii (Myrtaceae). In Ciampea, woody species found beyond the plot were Alstonia villosa (Apocynaceae), Nauclea obtusa (Rubiaceae), Ficus callosa (Moraceae), Hoya sp. (Asclepiadaceae), and Ficus benjamina (Moraceae).

The secondary vegetation in disturbed limestone were dominated by shrubs of Chromolaena (Compositae) and Lantana (Verbenaceae) particularly the lower slope. The quarried ones were also dominated by several species of grass and other herbaceous plants. In Ciampea, trees found in the succession include Pterospermum, Kleinhovia, and Macaranga which refer to effects of disturbance. In Nyungcung, the vegetation is less disturbed than that of Ciampea.

Invasive species such as Chromolaena and Melastoma as well as wild grass species were found abundantly in Ciampea, whereas in Nyungcung, as the site is relatively intact, the invasive species were relatively few.

\section{Rarity: current versus reported (1931) species}

Species found in Ciampea by van Steenis in 1931 i.e. Dipterocarpus hasseltii, Planchonia valida, Taraktogenos beterophylla, Stelechocarpus burahol, and Xerospermum noronbianum. These species were considered not frequently found in Java but recorded in Ciampea limestone hills, as well as annual species such as Epithema saxatilis, Begonia tenuifolia, Peperomia candida, Peperomia laevifolia, Monophyllaea horsfieldii, Rhynchoglossum obliquum, Zippelia, Argostemma, Sonerila, Cyrtandra pendula, Lerchea longicauda, Loxonia birsuta, Begonia isoptera. In our vegetation analysis, most of these annuals still exist.

According to Whitten and Soeriaatmadja (1997) based on the description of Ciampea limestone flora, surprisingly, Diospyros maritima can still be found albeit the specimen was found in coppice (resprouting). Apparently, none of the species found in Nyungcung and Ciampea limestone karsts belong to the IUCN Red List as expected. Native species endemic to the sites such as Zeuxine tjiampeana and Dipterocarpus hasseltii were also absent, this was perhaps due to the severity of quarrying activities. 
Furthermore, on steep limestone cliffs with bare rock faces, clefts and shelves, a distinctive herbaceous flora was found, for instance the Begonia sp. nov that is currently predicted to be a new species. A very distinctive Pandanus sp. was also found that needs further taxonomical investigation.

\section{Comparison to other limestone vegetation}

A total of 38 families were identified for Nyungcung and Ciampea sites. This was close to the number of families found in limestones forests on Bau Hill, Kuching Sarawak which was 41 families (Adam \& Mamat 2005) albeit the area of analysis covered 0.75 ha at three elevations whereas our study area covered only 0.043 ha. High disturbances also occurred in Sarawak limestone forest as in Nyungcung and Ciampea which were mostly caused by mining and human activities. The medium and small trees present under the canopy layer include Harpullia arborea, Chiosocheton beccarianus and Drypetes microphylla. Only Harpullia arborea shares common with our sites.

Furthermore, in Sarawak limestone forest, Moraceae, Fabaceae, Lauraceae, Euphorbiaceae, and Myrtaceae were families frequently encountered, while Ficus (Moraceae) was the species generally found in karsts areas (Adam \& Mamat 2005). A study by Roemantyo and Nurdjito, 2006 in Himakova IPB et al. 2007 confirmed also that Ficus, a member of Moraceae, are very abundant in number of species and density in both Bantimurung and Bulusaurung National Park in South Sulawesi. Ficus was found abundantly in both study sites, either terrestrial or (semi-) epiphytic species. Ficus montana and F. ampelas in Nyungcung, for instance, is a terrestrial; whereas F. hirta was (semi-) epiphytic. This was perhaps due to its ability to release liquid that dissolve limestone and coral and, therefore, receive enough minerals and water.

Roemantyo and Nurdjito (2006) in Himakova IPB et al (2007) mentioned that families found commonly in Bantimurung- Bulusaurung limestone national park were Euphorbiaceae, Fabaceae, Meliaceae, Moraceae, Sapindaceae, and Anacardiaceae. Another study by Amran (2005) in Himakova IPB et al (2007) showed that dominant families were Euphorbiaceae, Moraceae, and Rubiaceae. Moreover, similar to limestone vegetation of Nusa Barung in East Java (Whitten \& Soeriaatmadja 1997), Diospyros maritima (Ebenaceae), Croton tiglium (Euphorbiaceae) and Kleinhovia hospita (Sterculiaceae) were also found in Ciampea.

\section{Basal area and vegetation profile}

In Nyungcung hill, trees with height more than $15 \mathrm{~m}$ were hardly found, some resproutings from coppices are found in Nyungcung and Ciampea such as Garcinia sp., Artocarpus sp. in the former site and Diospyros sp., Cecropia sp., and Syzygium lineatum in the later site. Hence, the limestone of these sites could actually support tree species. High trees emerged in thicker soil covering the karst as has also been found in Sarawak (Adam \& Mamat 2005). Larger basal area in Nyungcung consisted of Araliaceae, Euphorbiaceae, Myrtaceae, and Staphyllaceae, whereas in Ciampea Euphorbiaceae, Myrtaceae, and Rubiaceae. 


\section{Climatic factor and floristic structure}

The soil pH in Ciampea was more alkaline (6.5-7) than in Nyungcung (5.3-6). The more acidic soil in Nyungcung was perhaps due to the decomposing leaf litter. Soil humidity in Nyungcung was 30-60\%, whereas in Ciampea was 60-92\%. Air temperature in Nyungcung and Ciampea were, respectively, $27.9-34.9^{\circ} \mathrm{C}$ and $27.7-$ $37.2^{\circ} \mathrm{C}$. Air humidity in Nyungcung and Ciampea were 70.4-80.6 and 60.2-77.3\%, respectively. The radiation in Nyungcung plot varied between 610-1669 Lux, whereas in Ciampea the radiation was $868-991.10^{6}$ Lux. Higher solar radiation received in Ciampea is due to the open area and density of vegetation.

The soil humidity and radiation were higher in Ciampea compared to Nyungcung, which might lead to different species composition. This finding is in line with Satrio (2005) in Himakova IPB et al (2007) who suggested that tree families variation of karsts areas were affected by altitude, local climate, depth of soil, stone's prime materials and soil humidity. In Ciampea, the plots consisted mostly of pioneer, shade intolerant species. The difference in floristic composition of both sites might be attributed to soil humidity and radiation difference, in addition to, the severity and duration of disturbance.

\section{Further research}

On the abandoned or old quarries, like in the lower part of Ciampea quarried hill, only invasive herbs and gramineous species can cope with the environment where the soil is highly compacted and hence, larger woody species cannot root successfully and the establishment is low due to the high competition. This is in accordance with the findings of old quarry in Guangdong China by Duan et al. (2008). In this old quarry, more than $90 \%$ of the species are gramineous and drought-tolerant. Furthermore, it is important to determine the soil seed bank of the limestone in order to know the availability and potential occurrence of the species in limestone. Further investigation of soil seed bank on limestone can be done to address this issue.

\section{CONCLUSIONS}

There was a difference in floristic composition in Nyungcung and Ciampea. A total of 38 families were recorded for both sites. Dominant families in Nyungcung were Euphorbiaceae, Myrtaceae, Sapotaceae, and Moraceae whereas in Ciampea, they were Euphorbiaceae, Sapindaceae, Moraceae, and Rubiaceae. Antidesma montanum is the most important species encountered in Nyungcung, whereas Macaranga rbizinoides that of in Ciampea. Native species endemic to the sites such as Zeuxine tjiampeana and Dipterocarpus hasseltii were also absent. None of the species found in Nyungcung and Ciampea limestone karsts belong to the IUCN Red List. 


\section{ACKNOWLEDGEMENTS}

This research project is sponsored by the Rufford Small Grant Foundation (Ref.RSG 4606 08) and we are grateful to the Hortus Botanicus Bogoriensis for the permission to keep the living specimens as the garden collection. We also would like to thank the two anonymous reviewers for their precious comments on the manuscript.

\section{REFERENCES}

Adam J.H. and Z. Mamat. 2005. Floristic composition and structural comparison of limestone forests at three different elevations in Bau, Kuching, Sarawak, Malaysia. Journal of Biological Sciences, 5 (4): 478-485.

Chin S.C. 1977. The limestone hill flora of Malaya: Part 1. Gardens' Bulletin Singapore, 30: 165220.

Chin S.C.1983. The limestone hill flora of Malaya: Part 4. Gardens' Bulletin Singapore, 36:31-91.

Clements R., Sodhi N.S., Schilthuizen M. and Ng P.K.L. 2006. Limestone Karst of Southeast Asia: Imperiled Arks of Biodiversity. BioScience, 56(9): 733-742.

Comber J.B. 1990. Orchids of Java. Royal Botanic Gardens Kew, UK.

Crowther J. 1982. Ecological observations in a tropical karst terrain, West Malaysia. I. Variations in topography, soils and vegetation. Journal of Biogeography. 11:65-78.

Duan W., H. Ren S. Fu, J. Wang, L. Yang and J. Zhang. 2008. Natural Recovery of Different Areas of A Deserted Quarry in South China. Journal of Environmental Sciences, 20: 476- 481.

Effendi A.C., Kusnama and B. Hermanto. 1998. Geological Map of Bogor Quadrangle, Java. Geological Research and Development Centre, Bandung.

HIMAKOVA IPB, Ministry of Forestry Government of Indonesia and WWF - USA. 2007. Scientific Report of Environment Conservation Study (SURILI) 2007: Karst Ecosystem Biological Diversity Assesment in Bantimurung Bulusaraung Nasional Park Province of South Sulawesi. Volume I Scientific Report. Collaboration between Forest Resources Conservation and Ecotourism Student Association (HIMAKOVA) Faculty of Forestry Bogor Agricultural University with Ministry of Forestry Government of Indonesia World and Wide Fund For Natural Resources - USA (WWF - USA), Bantimurung-Bulusaurung National Park, Province of South Sulawesi. August 10th-26th, 2007.

Oksanen J., F. G. Blanchet, R. Kindt, P. Legendre, R. B. O'Hara, G. L. Simpson, P. Solymos, M. Henry, H. Stevens, and H. Wagner. 2010. Vegan: Community Ecology Package. R package version 1.17-4. Http://CRAN.R-project.org/package $=$ vegan.

Fox J.<jfox@mcmaster.ca>, with contributions from Liviu Andronic, Michael Ash, Theophilius Boye, Stefano Calza, Andy Chang, Philippe Grosjean, Richard Heiberger, G. Jay Kerns, Renaud Lancelot, Matthieu Lesnoff, Uwe Ligges, Samir Messad, Martin Maechler, Robert Muenchen, Duncan Murdoch, Erich Neuwirth, Dan Putler, Brian Ripley, Miroslav Ristic and and Peter Wolf. 2010. Rcmdr: R Commander. R package version 1.6-1. http://CRAN.R-project.org/package=Rcmdr.

Kindt R. and R. Coe. 2005. Tree diversity analysis. A manual and software for common statistical methods for ecological and biodiversity studies. World Agroforestry Centre (ICRAF), Nairobi. ISBN 92-9059179-X.

Ko R.K.T., MD.DV., 1984. Peranan Ilmu Speleologi Dalam Penyelidikan Fenomena Karstik dan Sumberdaya Tanah dan Air Sebuah Informasi Soal Speleologi, Ceramah Pada Pusat Penelitian Tanah Bogor, Bogor.

Krebs C.J. 1999. Ecological Methodology Second Edition. Addison-Welsey Educational Publishers Inc.

Ludwig J.A. and J.F. Reynolds. 1988. Statistical Ecology a primer on methods and computing. John Wiley \& Sons, Inc. 
Proctor J., Anderson J.M., Fogden S.C.L. and H.W. Vallack. 1983a. Ecological studies in four contrasting lowland rain forests in Gunung Mulu National Park, Sarawak. I. Forest environment, structure and floristic. Journal of Ecology, 71:237-260.

Proctor J., Anderson J.M., Fogden S.C.L. and H.W. Vallack. 1983b. Ecological studies in four contrasting lowland rain forests in Gunung Mulu National Park, Sarawak. II. Litterfall, litter standing crops and preliminary observations on herbivory. Journal of Ecology, 71:261-283.

R Development Core Team 2010. R: A language and environment for statistical computing. R Foundation for Statistical Computing, Vienna, Austria. ISBN 3-900051-07-0, URL http://www.R-project.org/.

Whitten A.J. and R.S. Soeriaatmadja. 1997. The Ecology of Java and Bali. Periplus Editions, UK. 